\title{
Comparison of the effects of difenacoum and brodifacoum on the ultrastructure of rat liver cells
}

\author{
Nursel Gül ${ }^{1}$, Nuri Yiğit ${ }^{1}$, Fulya Sayg $11^{2}$, Ebru Demirel ${ }^{1}$, and Ceren Geniş ${ }^{1}$ \\ Department of Biology, Faculty of Science, University of Ankara, Ankaral ${ }^{l}$, Department of Biotechnology, Faculty of \\ Arts and Science, University of Niğde, Niğde ${ }^{2}$,Turkey
}

[Received in February 2015; CrossChecked in February 2015; Accepted in August 2016]

\begin{abstract}
We used transmission electron microscopy to examine the cytotoxic effects of the second-generation anticoagulant rodenticides difenacoum and brodifacoum on rat liver. A single dose of difenacoum or brodifacoum was administered to rats by gastric gavage and liver samples were taken after $24 \mathrm{~h}$, four days or seven days. In the livers of rats treated with difenacoum for $24 \mathrm{~h}$, hepatocytes typically showed increased numbers of lysosomes, as well as enlargement of both the perinuclear space and the cisternae of the rough endoplasmic reticulum (RER), while sinusoids were irregularly shaped and contained Kupffer cells. Similar irregularities occurred in brodifacoum-treated rats at the same time point, but additionally increased numbers of vacuoles, damaged mitochondrial cristae, and clumping of chromatin were observed in hepatocytes, and hemolysed erythrocytes were noted in the sinusoids. Comparable findings were made in each group of rats after four days. After seven days of difenacoum treatment, hepatocytes suffered loss of cytoplasmic material and mitochondrial shrinkage, while RER cisternae became discontinuous. In contrast, exposure to brodifacoum for seven days caused the formation of numerous vacuoles and lipid droplets, disordered mitochondrial morphology, chromatin clumping and invagination of the nuclear envelope in hepatocytes. Sinusoids in the livers of rodenticide-treated rats contained an accumulation of dense material, lipid droplets, cells with pycnotic nuclei and hemolysed erythrocytes. Overall, our results show that brodifacoum causes more severe effects in liver cells than difenacoum. Thus our microscopic data along with additional biochemical assays point to a severe effect of rodenticide on vertebrates.
\end{abstract}

KEY WORDS: hepatocyte; rough endoplasmic reticulum (RER); sinusoid; transmission electron microscopy (TEM); vacuole

Difenacoum and brodifacoum are synthetic secondgeneration anticoagulant rodenticides (SGARs) derived from coumarin. They are known to be more effective at targeting rats than indandione derivatives (1) and, compared to other SGARs, have good activity against the brown rat (Rattus norvegicus) and excellent activity against mice (2-6).

Difenacoum bait formulations against semi-wild and wild $R$. rattus (black rat) give excellent control in the field (7). Oral $\mathrm{LD}_{50}$ values for difenacoum are $1.8 \mathrm{mg} \mathrm{kg}^{-1}$ for rats, $2.0 \mathrm{mg} \mathrm{kg}^{-1}$ for rabbits. The dermal dose of difenacoum in rodents is somewhat higher, $>50 \mathrm{mg} \mathrm{kg}^{-1}$ for rats and rabbits (8). Difenacoum has been reported to act as a poison against both target (rodents) and non-target (e.g. human, dog, cat) animals (9-13). According to a research performed in France, accidental exposure to rodenticide is high in children aged 1-4, as well as in cats and dogs, with exposure rates of $41 \%$ in children and $85 \%$ in pet animals (12).

Brodifacoum has been widely used for the control of rodents since the mid-1970s $(5,14-18)$, and has a longer half-life in tissues than warfarin (19). The $\mathrm{LD}_{50}$ for brodifacoum is $1 \mathrm{mg} \mathrm{kg}^{-1}$ or less in mammals (20), and only

Correspondence to: Nursel Gül, Department of Biology, Faculty of Science, University of Ankara, Ankara, Turkey.

E-mail:ngul@science.ankara.edu.tr a single dose is needed for a lethal effect on rodents (21). However, there are multiple reports of non-target activity. Thus, Dowding et al. (2) pointed out that brodifacoum poisoning resulted in significant mortality of non-target animals, including domestic cats, as well as wild rabbits and birds, in an operation to eradicate rodents on Motuihe Island, New Zealand. Presumed in utero brodifacoum toxicity has been reported in the livers of two neonatal puppies with haemorrhage $(1,22)$, and brodifacoum can cause decreased sperm concentration, as well as an increase in dead and abnormal spermatozoa, in the testes and epididymis of Mus musculus (23). Poisoning of raptor populations has also been reported; for example, brodifacoum was detected at concentrations ranging from 0.001 to $0.927 \mathrm{mg} \mathrm{kg}^{-1}$ in the livers of three owls in western Canada (4). Clearly, SGARs are poisonous for both target and non-target animals, and there have been a number of studies on the cellular damage caused by these rodenticides. Transmission electron microscopy (TEM) showed that difenacoum perturbs organelle structure in rat liver cells, for example, causing nuclear shrinkage, proliferation of lipid droplets, and destruction of the endoplasmic reticulum (ER) and mitochondria (6). Binev et al. (24) used light microscopy to show that bromadiolone, another SGAR, 
causes degeneration of liver, lung, and kidney cells in pheasants.

Although both difenacoum and brodifacoum are widely used rodenticides, there are no published comparisons of their cytotoxic effects on the liver cells of target animals. In this report, we describe the ultrastructural studies which show that, while both SGARs cause devastating damage to liver cells and associated structures, brodifacoum is more hepatotoxic than difenacoum.

\section{MATERIALS AND METHODS}

\section{Experimental animals}

Adult male rats (Wistar albino, 7-9 weeks old, 190$230 \mathrm{~g}$ body weight) were used in this study following the ethical approval from the Ankara University Ethics Committee. The animals were divided into seven groups ( $n=5$ for each group) for SGAR (difenacoum and brodifacoum) treatments: a control (untreated) group, $24 \mathrm{~h}$, four days, and seven days. Each animal was kept in a separate cage at room temperature with a photoperiod of 12:12 h light-dark and $65 \%$ humidity. Animals were quarantined for seven days before the experiments (14).

\section{Experiments with difenacoum and brodifacoum}

SGAR doses under the $\mathrm{LD}_{50}$ were applied to the samples in order to determine the chronic cytotoxic effects. Thus a single dose of difenacoum $\left(0.8 \mathrm{mg} \mathrm{kg}^{-1}\right)$ or brodifacoum $\left(0.2 \mathrm{mg} \mathrm{kg}^{-1}\right)$ dissolved in DMSO/polyethylene glycol (PEG)-400/water $(0.02 \mathrm{~mL} / 1 \mathrm{~mL} / 1 \mathrm{~mL})$ was orally administered by gastric gavage to each animal in the assay groups. A single dose $\left(1 \mathrm{~mL} \mathrm{~kg}^{-1}\right)$ of DMSO/PEG-400/water was given orally by gastric gavage to control group rats at the same time (21). All rats were fed standard laboratory diet and water during the experiment. Rodenticide-treated animals were killed by cervical dislocation after $24 \mathrm{~h}$, four days, or seven days and liver tissues were obtained for examination by TEM. Control group rats were sacrificed after seven days (14).

\section{Transmission electron microscopy}

Tissue samples for TEM were immersed in $2.5 \%$ glutaraldehyde buffered to $\mathrm{pH} 7.4$ with $0.1 \mathrm{mmol} \mathrm{L}^{-1}$ sodium phosphate, and kept cold for $2 \mathrm{~h}$. After rinsing three times in cold sodium phosphate buffer, the tissues were post-fixed in $1 \%$ osmium tetroxide solution for $2 \mathrm{~h}$ at $4{ }^{\circ} \mathrm{C}$. Fixed tissues were dehydrated in a series of graded ethanols, placed into propylene oxide, and embedded in araldite (25). Ultrathin sections were stained with $2 \%$ uranyl acetate and lead citrate and examined at $80 \mathrm{kV}$ using a JEOL $100 \mathrm{CX}$ II (JEOL, Ltd. Tokyo-JAPAN) microscope in the Biology Department, Faculty of Science, Ankara University.

\section{RESULTS}

The rats exposed to rodenticides displayed behavioural disorders and external haemorrhage after $24 \mathrm{~h}$ of exposure, with mortality ensuing within seven days, accompanied by haemorrhage in the eyes, nose, and mouth. Morphological examination showed the livers of these rats to be discoloured and enlarged compared to those of control group rats.

Our results demonstrate that difenacoum and brodifacoum have destructive effects on the structure of liver cells, for example, causing marked alteration of organelle morphology. In control rats, TEM showed that hepatocytes contained a circular or oval-shaped nucleus with fine granular components and chromatin condensation of the nucleoplasm, regular-shaped rough endoplasmic reticulum (RER) and mitochondria, cytoplasmic granules, randomly located glycogen granules, and a homogeneous cytoplasm. The sinusoidal space in these animals appeared regular in shape and contained homogeneous separate fine granular material (Figure 1).

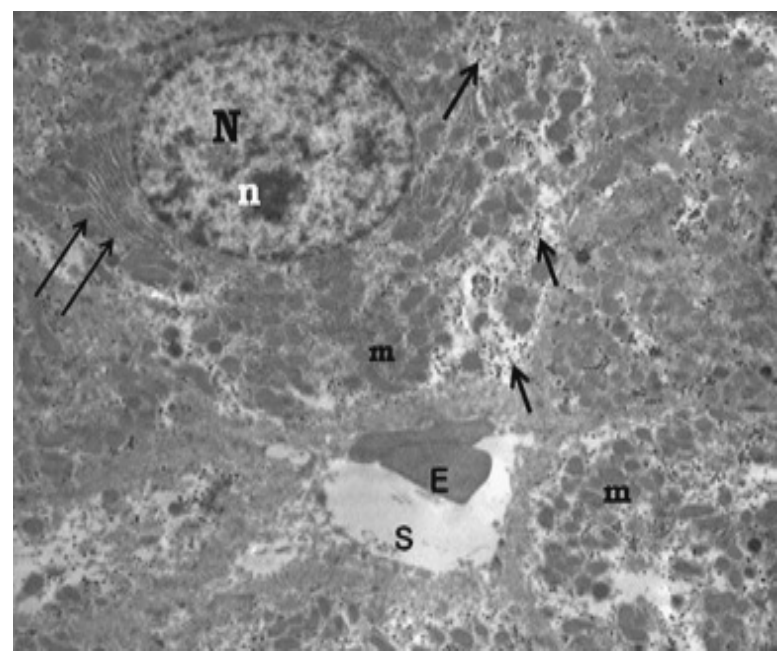

Figure 1 The liver of control group rats. Mitochondria (M), rough endoplasmic reticulum (double arrow), nucleus (N), nucleolus (n), glycogen (single arrow), sinusoid (S), erythrocytes (E). (1000x)

In contrast, livers from rats treated with difenacoum for $24 \mathrm{~h}$ showed structural changes such as damaged mitochondrial cristae and enlargement of both the RER cisternae and the perinuclear space (Figure 2). The hepatocyte cytoplasm showed vacuolisation, with many cisternae in the RER and clumping of chromatin in the nucleoplasm. The sinusoids were irregularly shaped and contained many Kupffer cells and disordered hepatocytes with hyalinisation of the mitochondrial matrix and fusion of mitochondrial membranes; there were also numerous sinusoid-proximal lysosomes in these cells (Figure 3). The presence of Kupffer cells in the sinusoid may indicate the degree of poisoning with difenacoum.

In rats exposed to difenacoum for four days, liver cells had a markedly different structure to those of the control group. A lot of lysosomes/autophagosomes, few glycogen 


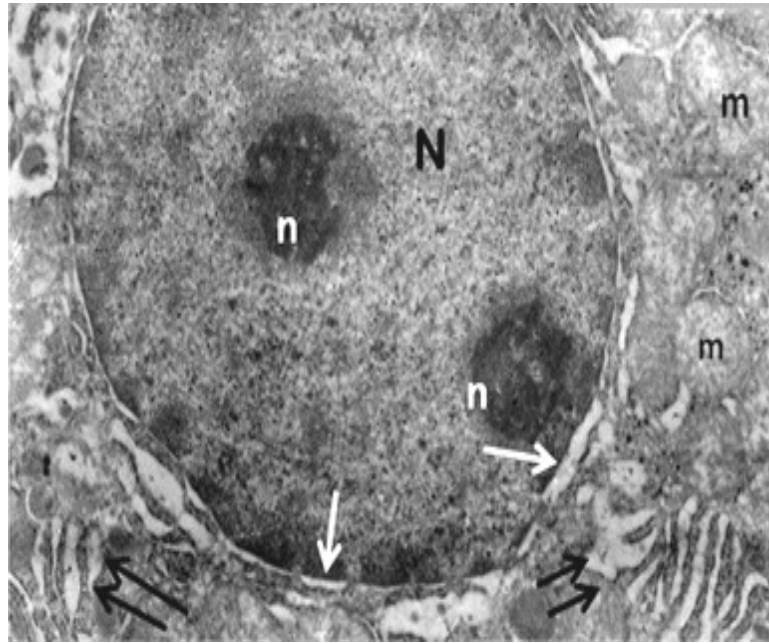

Figure 2 Enlarged cisternae of rough endoplasmic reticulum (double arrow) and nuclear envelope (single arrow), nucleus (N), nucleolus (n), and damaged cristae of mitochondria (m) of $24 \mathrm{~h}$ difenacoum-treated rat hepatocytes. $(7200 x)$

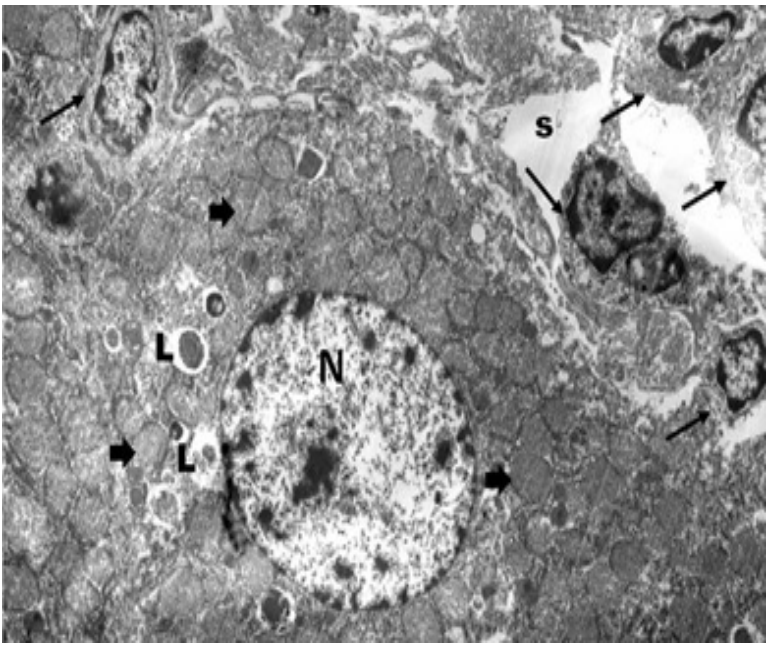

Figure 3 Sinusoid (S) filled with Kupffer cells (single arrow) and hepatocyte contained many lysosomes ( $L$ ) and mitochondrial cristae damaged (bold arrow) in the $24 \mathrm{~h}$ brodifacoum-treated rat livers. $(2900 x)$

granules, enlarged mitochondria, and mitochondrial membrane fusion were observed. As an indication of the immune response, a plasma cell was observed in the sinusoid of four days difenacoum-treated rat liver (Figure 4). In the case of brodifacoum treatment for four days, TEM also showed abnormal structure of the hepatocyte nucleus, such as invagination of the nuclear envelope, clumping of chromatin, and localisation of chromatin near the nuclear envelope. In the thin sections of the liver cells of these animals, the melting of mitochondrial cristae and lysosomes were again observed (Figure 5). Erythrocytes with disrupted cytoplasmic materials, Kupffer cells, and an accumulation of dense material were seen in the sinusoid. Hepatocytes around the sinusoid had an abundance of mitochondria with damaged cristae and lysosomes (Figure 6).

In rats treated with difenacoum administered for seven days, hepatocytes contained mitochondria of varying sizes,

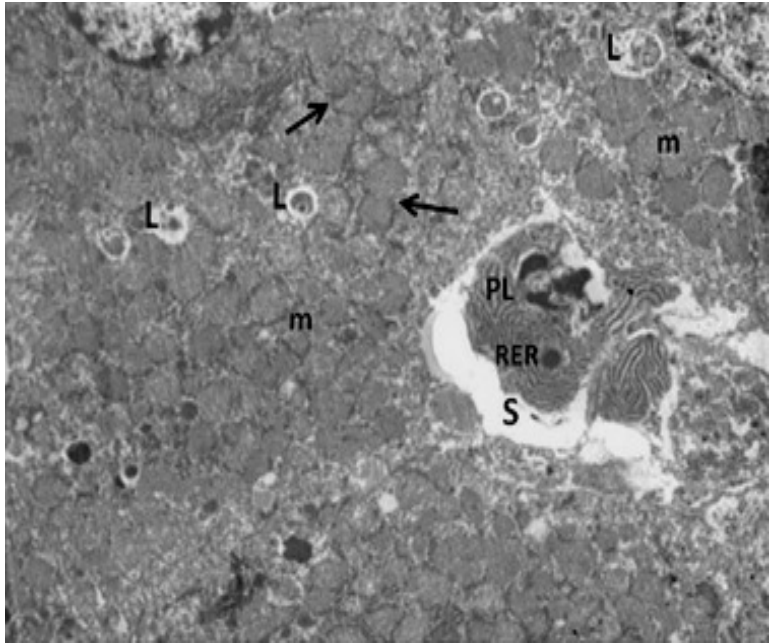

Figure 4 Four days difenacoum-treated rat liver with deformed hepatocytes and plasma cell in the sinusoid. Lysosome (L), plasma cell (PL), rough endoplasmic reticulum (RER), mitochondria ( $m$ ), mitochondrial membrane fusion (single arrow). (5800 x)

from small to large, RER with discontinuous cisternae, few glycogen granules, and focal necrotic areas (Figure 7). Additionally, structural irregularities were apparent in the enlarged sinusoid, an accumulation of dense material, loss of cytoplasmic material in Kupffer cells, as well as hepatocytes (Figure 8). After seven days, the livers of brodifacoum-treated rats contained hepatocytes with invagination of the nuclear envelope, chromatin clumping, structural residues in lysosomes, damaged mitochondrial cristae, mitochondrial membrane fusion, Kupffer cells, and cellular residues in the enlarged sinusoid. Further signs of severe liver damage in these rats included the variation of the size of mitochondria, as well as damaged cristae and membrane fusion in mitochondria, lipid droplets and lysosomes in hepatocytes. Hepatocytes were thoroughly corrupted ultrastructurally, for example, containing

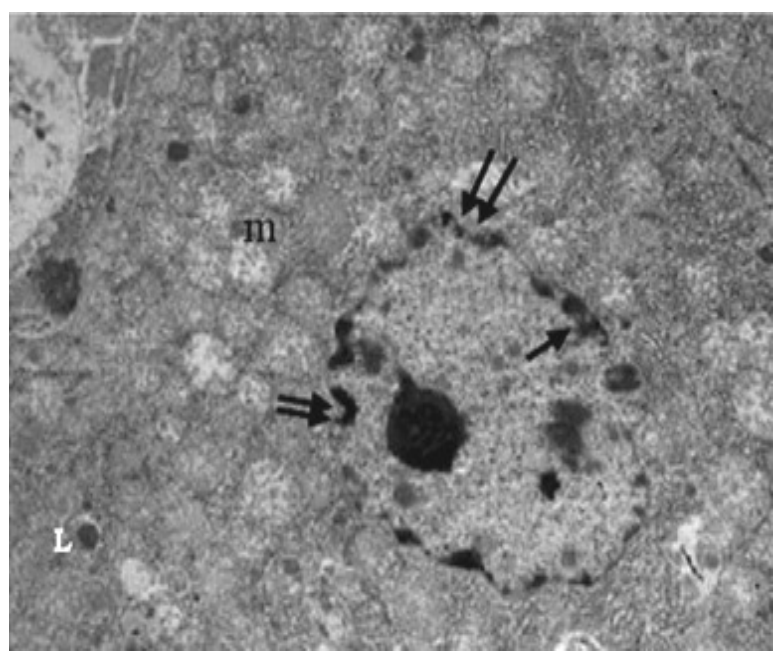

Figure 5 Damaged cristae of mitochondria $(\mathrm{m})$, lysosome (L), invagination of nuclear envelope (double arrow), localisation of chromatin material (single arrow) in the four days brodifacoumtreated rat hepatocytes. $(5800 x)$ 


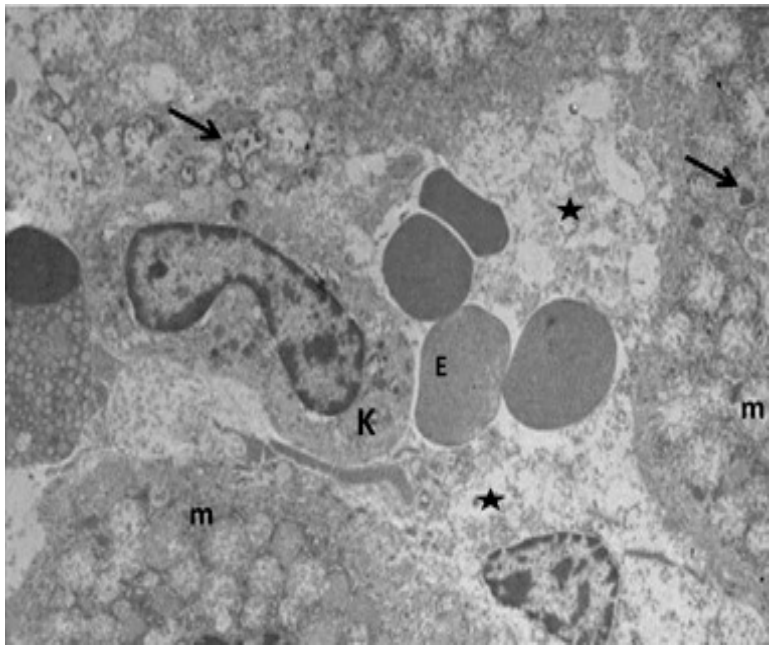

Figure 6 Liver cells of four days brodifacoum-treated rats. Erythrocyte (E), Kupffer cell (K), mitochondria with damaged cristae (m), cellular residue (star), lysosome (single arrow). (5800x)

numerous lipid droplets, damaged and misshaped mitochondria that were often fused to each other, and necrotic nuclear material in their cytoplasm (Figure 9).

\section{DISCUSSION}

In this study, we confirmed that the SGARs brodifacoum and difenacoum have different harmful effects on rat liver cells such as damaged mitochondrial cristae, discontinuous RER cisternae, many lysosomes, lipid droplets, and nuclear abnormalities in the hepatocytes. Littin et al. (15) reported that Norway rats and possums displayed behavioural disorders, pathologic changes, and even death after poisoning with brodifacoum. When dead animals were autopsied, internal bleeding was evident alongside other cytotoxic effects. These findings are consistent with our results and are also reported in previous studies by Lechevin and Vigie (26). We observed that, $24 \mathrm{~h}$ after receiving brodifacoum, rats showed behavioural disorders, while eyes, mouth, and nose bleeding occurred around the fourth day. By the sixth day, most animals were dead. It was also noted that the animals monitored showed internal bleeding and developed necrosis in their livers due to the anticoagulant poison. Revathi and Yogananda (27) gave bromadiolone to mice (Mus musculus) orally and observed an enlargement of their livers, and cytoplasmic vacuolisation in hepatocytes, as well as necrosis and accumulation of toxic debris. These findings are consistent with our own, particularly the increase in vacuoles and necrosis on the seventh day. According to DuVall et al. (28), reporting a study performed in 1986-1987, some cats and dogs poisoned by a rodenticide showed swollen hepatocyte vacuoles and an accumulation of substances in sinusoids, together with subcutaneous bleeding. This fits with our findings that, after four and seven days of brodifacoum treatment, rats increased vacuolisation in hepatocytes and haemolysed erythrocytes.
Dowding et al. (2) reported an average brodifacoum level of $0.84 \mu \mathrm{g} \mathrm{g}^{-1}$ in the livers of 29 dead individuals belonging to ten bird species. Brodifacoum residues were also detected in the livers of target and non-target animals by high performance liquid chromatography $(2,3,13,22,29)$. In our study, the ultrastructure of the liver of rats given a dose of brodifacoum was severely affected, and these effects were particularly marked after the fourth and seventh days. When we examined the liver cells of difenacoum-treated rats by TEM, the primary morphological change was a loss of cytoplasmic material. Additionally, we observed accumulation of substances in the sinusoids. The consequences of accidental exposure to anticoagulant rodenticides in humans and non-target animals include physiological defects such as the inhibition of the vitamin $\mathrm{K}$ cycle, anaemia, hypoproteinaemia, hypalbuminaemia,

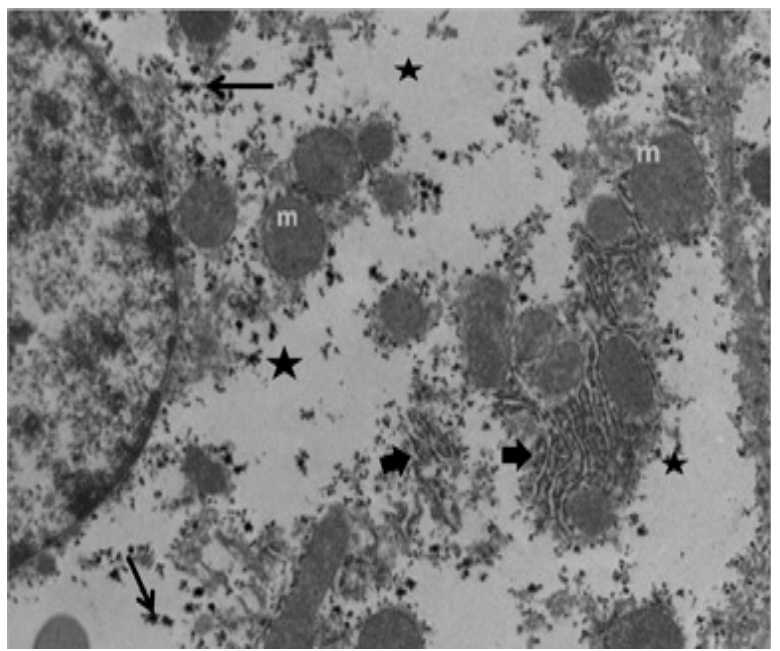

Figure 7 Hepatocyte degeneration of seven days difenacoumtreated rat livers. Mitochondria ( $m$ ), focal necrotic area (star), discontinuous RER cisternae (bold arrow), a few glycogen grains (single arrow). (10000 x)

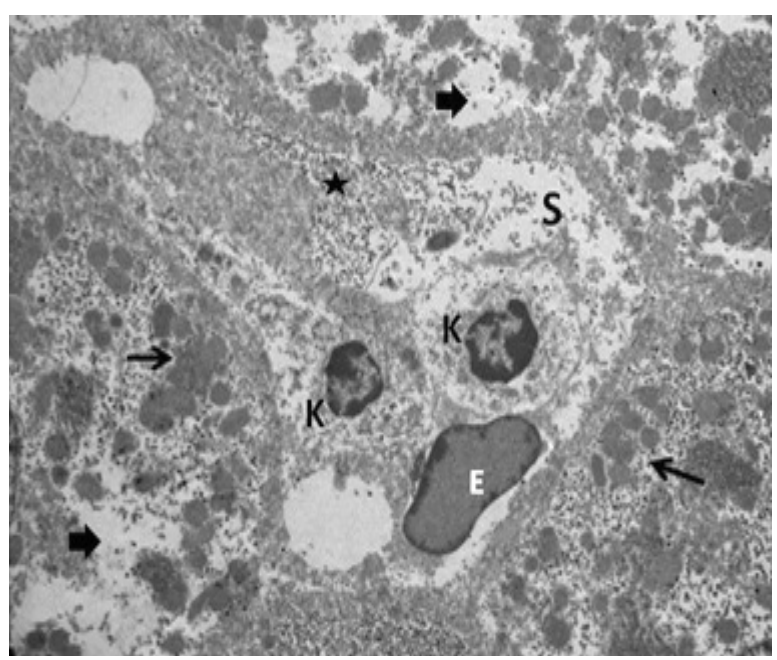

Figure 8 Liver of seven days difenacoum-treated rat liver. Erythrocyte (E), accumulation of electron dense material (star), Kupffer cell (K), loss of cytoplasmic area in the hepatocytes (bold arrow), mitochondria (single arrow), sinusoid (S). (5800 x) 


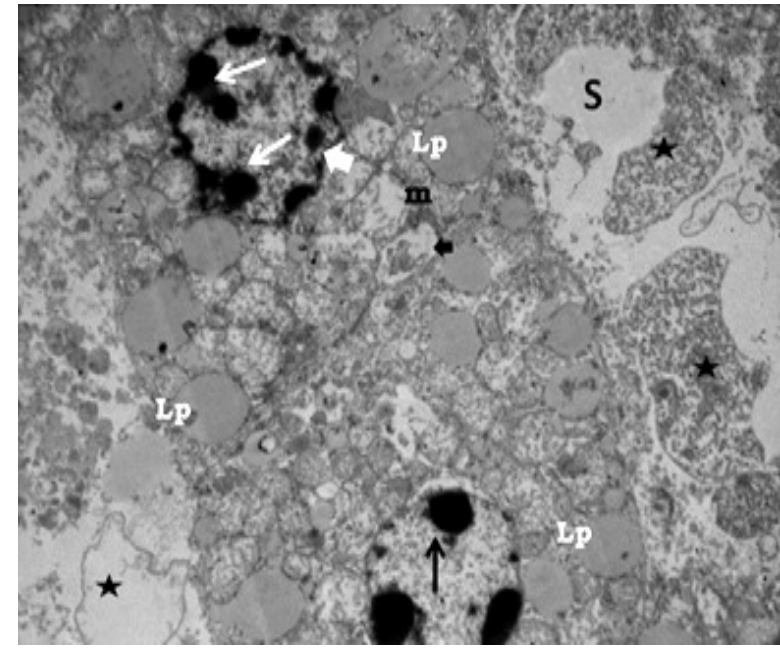

Figure 9 Ultrastructural deformation in the hepatocytes of seven days brodifacoum-treated rats. Chromatin clumping in the nucleus (single arrow) and invagination of nuclear envelope (bold arrow), lipid droplets (Lp), autophagosome (bold arrow), damaged cristae of mitochondria (m), cellular residues (star), sinusoid (S). (7200x)

hyperglycaemia, and bilirubinaemia; other adverse effects include an increase in active coagulation time, oedema in the lungs, tachycardia, haemorrhage, skin hyperaemia, and nose, ear, and vagina bleeding (18). Difenacoum-treated rats also showed nose and ear bleeding after four and seven days of treatment. Exposure to another SGAR, bromadiolone, led to multiple necrotic areas in the liver, hyperplasia of bile ducts, strong hyperaemia and haemorrhage, and siderocytes in lung parenchyma, vacuolisation of the cytoplasm with karyolysis, and karyopyknosis of tubular epithelial cells in the pheasant kidney (24). Similar findings were observed in our anticoagulant-treated rats after four and seven days in respect of the vacuolisation and karyolysis of hepatocyte cytoplasm and the presence of haemolysed erythrocytes in the sinusoid.

An electron microscopy study in rats showed that difenacoum, at doses of $0.25 \mathrm{mg} \mathrm{kg}^{-1}$ and $0.5 \mathrm{mg} \mathrm{kg}^{-1}$, was highly cytotoxic and had severe effects on the liver ultrastructure, including the compression of sinusoids and enlargement of Kupffer cells; in hepatocytes, necrotic nuclei, cytoplasmic vacuolisation, lipid droplets, disrupted RER cisternae and mitochondria were observed (26). This is reminiscent of our results on liver organelles after rats were treated with a $0.8 \mathrm{mg} \mathrm{kg}^{-1}$ dose of difenacoum.

\section{CONCLUDING REMARKS}

As a result, when the effect of the two rodenticides was compared across treatment groups, brodifacoum was found to cause greater damage to cell organelles than difenacoum. The most marked differences were an increased number of lipid droplets and lysosomes, a necrotic nucleus, discontinuous RER cisternae, and mitochondrial deformity after exposure to brodifacoum. These electron microscopic and morphological observations will provide the basis for further research on the cytotoxic effects of anticoagulant rodenticides.

\section{REFERENCES}

1. Fisher P, O'Connor C, Wright G, Eason CT. Persistence of four anticoagulant rodenticides in livers of laboratory rats. DOC Science Internal Series 139, 2003 [displayed 12 July 2016]. Available at http://www.doc.govt.nz/documents/ science-and-technical/dsis139.pdf

2. Dowding JE, Murphy EC, Veitch CR. Brodifacoum residues in target and non-target species following an aerial poisonning operation on Motuihe Island, Hauraki Gulf, New Zealand. New Zealand J Ecol 1999;23:207-14.

3. Albert CA, Wilson LK, Mineau P, Trudeau S, Elliott JE. Anticoagulant rodenticides in three owl species from Western Canada, 1988-2003. Arch Environ Contam Toxicol 2010;58:451-9. doi: 10.1007/500244-009-9402-z

4. Dowding CV, Shore RF, Worgan A, Baker PJ, Harris S. Accumulation of anticoagulant rodentiside in non-target insectivore, the European hedgehog (Erinaceus europaeus). Environ Poll 2010;158:161-6. doi: 10.1016/j.envpol. 2009.07.017

5. Patocka J, Petroianu G, Kuca K. Toxic potential of superwarfarin: Brodifacoum. Mil Med Sci Lett (Voj. Zdrav. Listy) 2013;82:32-8.

6. El-Daly AA, Nassar SA. Anticogulant Difenacoum-induced histological and ultrastructural alterations in liver of albino rats. Int J Adv Res 2014;2:782-92.

7. Hughes S. Efficacy of Difenacoum bait formulations against semi- wild and wild Rattus rattus from three different global locations. In: Robinson WH, Bajomi D, editors. Proceedings of the 6th International Conference on Urban Pests; 13-16 July 2008; Budapest, Hungary. Veszprém: OOK-Press Kft.; 2008. p. 297-300.

8. Norström K, Remberger M, Kaj L, Potter A, Cousins AP, Brorström-Lundén E. Results from the Swedish National Screening Programme 2008 Subreport 3. Biocider: Difenacoum. Stockholm: IVL Swedish Environmental Research Institute Ltd.; 2008.

9. Redfern R, Gill JE. The development and use of a test to identify resistance to the anticoagulant difenacoum in the Norway rat (Rattus norvegicus). J Hyg Camb 1978;81:42731. PMID: 731023

10. Lund M. Comparative effect of the three rodenticides warfarin, difenacoum and brodifacoum on eight rodent species in short feding periods. J Hyg Camb 1981;87:101-7. PMCID: PMC2134080

11. Ganser LR, Hopkins WA, O'Neil L, Hasse S, Roe JH, Sever DM. Liver histopathology of the southern watersnake, Nerodia fascita fascita, following chronic exposure to trace element-contaminated prey from a coal ash disposal site. J Herpetol 2003;37:219-26. doi: 10.1670/0022-1511(2003)037 [0219:LHOTSW]2.0.CO;2

12. Berny P, Velardo J, Pulce C, D'amico A, Kammerer M, Lasseur R. Prevalance of anticoagulant rodenticide poisoning in humans and animals in France and substances involved. Clin Toxicol 2010;48:935-41. doi: 10.3109/15563650. 2010.533678 
13. Elmeros M, Christensen TK. Concentrations of anticogulant rodenticides in stoats Mustela erminea and weasels Mustela nivalis from Denmark. Sci Total Environ 2011;409:2373-8. doi: 10.1016/j.scitotenv.2011.03.006

14. Hadler MR, Buckle AP. Forty five years of anticoagulant rodenticides - past, present and future trends. In: Borrecco JE, Marsh RE, editors. Proceedings of the Fifteenth Vertebrate Pest Conference; 3-5 March 1992; Newport Beach, California. Davis: University of California; 1992. p. 149-55.

15. Littin KE, O'Connor CE, Eason CT. Comparative effects of brodifacoum on rats and possum. New Zealand Plant Protection 2000;53:310-15.

16. Vandenbroucke V, Bousquet-Melou A, DeBacker P, Croubels $\mathrm{S}$. Pharmacocinetics of eight anticoagulant rodenticides in mice after single oral administration. J Vet Pharmacol Therap 2008;31:437-45. doi: 10.1111/j.1365-2885.2008.00979.x

17. Broll A, Esther A, Schenke D, Jacob J. Anticoagulant rodenticides: exposure and residues in non-target rodents and their predators. Julius-Kühn-Archiv 2011;432:145. doi: 10.5073/jka.2011.432.079

18. Buckle A. Anticoagulant resistance in the UK and a new guideline for the management of resistant infestations of Norway rats (Rattus norvegicus Berk.). Julius-Kühn-Archiv 2011;432:61-2. doi: 10.5073/jka.2011.432.029

19. Lee Ju-Hee, Kim H, Han H, Lee K, Kim S. A case of superwarfarin intoxication without a definitive history of brodifacoum exposure. Korean J Hematol 2009;44:53-7. doi: 10.5045/kjh.2009.44.1.53

20. Eason CT, Ogilvie S. A re-evaluation of potential rodenticides for aerial control of rodents. DOC Research and Development Series 312 [displayed 13 July 2016]. Available at http://www. doc.govt.nz/documents/science-and-technical/drds312entire. pdf

21. Mosterd JJ, Thijssen HHW. The long-term effects of the rodenticide, brodifacoum, on blood coagulation and vitamin
K metabolism in rats. Br J Pharmacol 1991;104:531-5. doi: 10.1111/j.1476-5381.1991.tb12463.x

22. Munday JS, Thompson LJ. Brodifacoum toxicosis in two neonatal puppies. Vet Pathol 2003;40:216-9. doi: 10.1354/ vp. $40-2-216$

23. Mohamed NG, Kadhim AHH. The effect of brodifacoum on the reproduction of male wild house Mus musculus (Muridae: Rodentia). Ibn Al-Haitham J Pure Appl Sci 2006;19:1-8.

24. Binev RG, Valchev I, Groseva N, Lazarov L, Hristov T, Uzunova K. Morphological investigations of experimental acute intoxication with the anticoagulant rodenticide bromadiolone in pheasants. İstanbul Üniv Vet Fak Derg 2012;38:161-73.

25. Hayat MA. Principle and Techniques of Electron Microscopy. Biological applications. Vol. 2. New York (NY): Van Nostrand Reinhold Company, 1972.

26. Lechevin JC, Vigie A. Which useful toxicological information can be drawn from studies on the hepatic fixation of anticoagulant rodenticides. In: Borrecco JE, Marsh RE, editors. Proceedings of the Fifteenth Vertebrate Pest Conference; 3-5 March 1992; Newport Beach, California. Davis: University of California; 1992. p. 45.

27. Revathi K, Yoganonda M. Effect of bromadiolone on haematology, liver and kidney in Mus musculus. J Environ Biol 2006;27:135-40. PMID: 16850891

28. DuVall M, Murphy M, Ray A, Reagor J. Case studies on second-generation anticoagulant rodenticide toxicities in nontarget species. J Vet Diagn Invest 1989;1:66-8. doi: 10.1177/104063878900100118

29. Hernandez-Moreno D, De La Casa-Resino I, Lopez-Beceiro A, Fidalgo LE, Soler F, Perez-Lopez M. Secondary poisoning of non-target animals in an ornithological zoo in Galicia (NW Spain) with anticoagulant rodenticides: a case report. Vet Med 2013;58:553-9.

\section{Usporedba učinaka difenakuma i brodifakuma na ultrastrukturu jetara štakora}

Transmisijskim elektronskim mikroskopom ispitivali smo citotoksične učinke druge generacije antikoagulacijskih rodenticida difenakuma i brodifakuma na jetra štakora. Štakori su dobili jednu dozu difenakuma ili brodifakuma gavažom, a uzorci jetara uzeti su nakon 24 sata te nakon četiri ili sedam dana. U hepatocitima štakora kojima je dan difenakum tijekom 24 sata uočen je povećan broj lizosoma te povećanje perinuklearnoga prostora i cisterne hrapavog endoplazmatskog retikuluma (eng. Rough Endoplasmic Reticulum - RER), a sinusoidi su bili nepravilnog oblika i sadržavali su Kupfferove stanice. Slične su nepravilnosti uočene i u štakora koji su tretirani brodifakumom u istom razdoblju, ali su uz to primijećeni i povećan broj vakuola, oštećene mitohondrijske kriste i nakupljanje kromatina u hepatocitima te hemolizirani eritrociti u sinusoidima. Nakon četiri dana nalazi su bili usporedivi u svim skupinama štakora. Nakon sedam dana tretiranja difenakumom, $u$ hepatocitima je uočen gubitak citoplazmatskog materijala i smanjenje mitohondrija, a cisterne RER-a postale su isprekidane. Izloženost brodifakumu tijekom sedam dana uzrokovala je stvaranje različitih vakuola i lipidnih kapljica, poremećaj mitohondrijske morfologije, nakupljanje kromatina i invaginaciju nuklearne omotnice u hepatocitima. U sinusoidima jetara štakora koji su tretirani rodenticidom primijećeno je nakupljanje gustog materijala, lipidnih kapljica, stanica s piknotičkim nukleusima i hemoliziranih eritrocita. Općenito, naši rezultati upućuju na to da brodifakum uzrokuje ozbiljnije učinke u jetrenim stanicama od difenakuma. Naši podaci dobiveni mikroskopskim ispitivanjem i ostalim biokemijskim testovima govore u prilog štetnom učinku rodenticida na kralježnjake. 